\title{
Concise Commentary: Second Line Is Not Second Best-Continuing Validity of the Oxford Criteria in the Management of Acute Severe Ulcerative Colitis
}

\author{
Pauline Rivière $^{1} \cdot$ David Laharie $^{1} \cdot$ Philippe Marteau $^{2,3}$ \\ Published online: 5 September 2019 \\ (c) Springer Science+Business Media, LLC, part of Springer Nature 2019
}

Acute severe ulcerative colitis (ASUC), as the most lethal complication of inflammatory bowel disease, often necessitates referral of patients to specialized centers staffed with trained medical and surgical teams [1]. First-line therapy is intravenous (IV) steroids, justified by over 50 years of experience that has documented the induction of clinical remission in $\sim 65 \%$ of cases [2]. Cyclosporine or infliximab, used as second-line therapy, is effective in the setting of steroid resistance [3]. If the disease does not respond to this second-line therapy or at any time when peritoneal symptoms are manifest, colectomy is indicated. Surgery is also often indicated in initial responders if the disease relapses after a short period of time; $20-30 \%$ of relapsers require colectomy at 1 year [4]. Until now, modifying the infusion schedule or doses has not been associated with significant improvement [5].

Timely decision making is essential to therapeutic decision making, i.e., using first-line or second-line medical treatments or referring the patient for surgery $[1,2]$. Travis et al. showed in 1996 (at a time when second-line therapy was not used) that bowel movement frequency $>8$ /day and C-reactive protein $>45 \mathrm{mg} / \mathrm{l}$ after 3 days of steroids were factors that accurately predicted colectomy risk [6]. These "Oxford criteria" have been used since then, with the modification that second-line therapy is recommended when steroids fail at treatment day 3 [6].

Philippe Marteau

philippe.marteau@aphp.fr

1 Department of Hepatogastroenterology and Digestive Oncology, Haut-Lévêque Hospital, CHU de Bordeaux, Bordeaux, France

2 Sorbonne Université - INSERM-ERL 1157, CHU Saint-Antoine 27 - UMR7203 - Saint Antoine IBD Network, APHP, Hôpital Saint Antoine, Paris, France

3 Hepatology and Gastroenterology, Hôpital Saint Antoine, 184 Faubourg St Antoine, 75012 Paris, France
The study by Moore and Bressler published in this issue of Digestive Diseases and Sciences evaluated the predictive value of the Oxford criteria in patients with ASUC who received second-line therapy when needed (infliximab except for one patient who received cyclosporine and vedolizumab) [7]. The authors retrospectively collected 80 patients with ASUC treated with IV steroids, comparing the colectomy rate according to the presence or absence of Oxford criteria. Patients fulfilling the Oxford criteria had a higher risk of colectomy during hospital admission (12/33 [36\%] vs. $4 / 41$ of those who did not meet the criteria [10\%], $p=0.009)$. This article thus confirms that the Oxford criteria are still relevant to the modern management of ASUC. Furthermore, it shows (and this is what we should tell our patients) that when these criteria are used in real-life conditions, the risk of colectomy is one-third during hospital admission and $45 \%$ in the first 90 days. Of course, larger series from different centers may improve the precision of these data although they seem to reflect what is commonly observed in daily practice. Informing patients with ASUC of these risks should help better inform patients and help them to be better prepared regarding the decision of surgery.

\section{References}

1. Ordás I, Domènech E, Mañosa M, et al. Post-operative morbidity and mortality of a cohort of steroid refractory acute severe ulcerative colitis: nationwide multicenter study of the GETECCU ENEIDA Registry. Am J Gastroenterol. 2018;113:1009-1016.

2. Harbord M, Eliakim R, Bettenworth D, et al. Third European evidence-based consensus on diagnosis and management of ulcerative colitis. Part 2: current management. J Crohns Colitis. 2017;11:769-784.

3. Laharie D, Bourreille A, Branche J, et al. Ciclosporin versus infliximab in patients with severe ulcerative colitis refractory to intravenous steroids: a parallel, open-label randomised controlled trial. Lancet Lond Engl. 2012;380:1909-1915. 
4. Laharie D, Bourreille A, Branche J, et al. Long-term outcome of patients with steroid-refractory acute severe UC treated with ciclosporin or infliximab. Gut. 2018;67:237-243.

5. Sebastian S, Myers S, Nadir S, Subramanian S. Systematic review: efficacy and safety of accelerated induction regimes in infliximab rescue therapy for hospitalized patients with acute severe colitis. Dig Dis Sci. 2019;64:1119-1128.

6. Travis SP, Farrant JM, Ricketts C, et al. Predicting outcome in severe ulcerative colitis. Gut. 1996;38:905-910.
7. Moore AC, Bressler B. Acute severe ulcerative colitis: the Oxford criteria no longer predict in-hospital colectomy rates. Dig Dis Sci. (Epub ahead of print). https://doi.org/10.1007/s10620-019-05668-6.

Publisher's Note Springer Nature remains neutral with regard to jurisdictional claims in published maps and institutional affiliations. 